・第 8 回日本ゴム協会賞受賞者報告・

\section{OA 用エラストマー精密パーツの開発}

(電子写真装置用ゴム部品)

バンドー化学株式会社

\section{藤原良則, 迫 康浩, 田口善男 岡崎貴彦, 武居正史}

この度は, 名誉あるゴム協会賞の受賞の栄に浴し， 大変光栄に存じます，以下，開発してきました技術と その製品について要約を御説明いたします。

\section{1. 電子写真装置におけるゴム部品について}

電子写真は，複写機，プリンターおよびファクシミ リ技術の主流であり, オフィス出力機器の要の技術と なっております。

近年, オフィスに適した小型・低価格・高画質で, 環境マージンが広く, かつオゾン発生量の少ない電子 写真技術の開発が急速に進んでおり，このような観点 から見ると心臟部である感光体周りは，带電・現像・ 転写の各ローラー, 並びに現像・クリーニング・シー ルの各ブレード等のようにすべてゴム材料で構成され つつあり，いずれも高い信頼性の要求される精密な高 機能部品です。

\section{2. 技術開発の構成について}

電子写真技術の急速な進歩に伴い, 心藏部に使用さ れるゴム部品に対する要求も急速に高性能化されてき ており,従来技術の延長線では, 飛躍的な技術革新及び ニーズにマッチした開発スピードに限界があります。

当社は，ポリウレタンゴムの分子設計・高次構造設 計を核に・応力・ひずみ解析，破壊特性の向上，非破 壊特性の制御の技術を結びつけることで，新しい技術 開発を実施いたしました。

\section{3. 技術開発事例について}

より信頼性の高いブレードクリーニングとして，ク リーニングブレードに要求される特性は,

・低硬度でありながら, 高伸張モジュラスが高いこと。 ・粘弾性特性の環境温度依存性が少ないこと.

・永久ひずみが小さいこと.

・物性值を保持したまま摩擦係数を制御できること。 等であります。

これらは，いずれも従来の化学組成に依存する分子 設計の範疇では，両立しないものです。

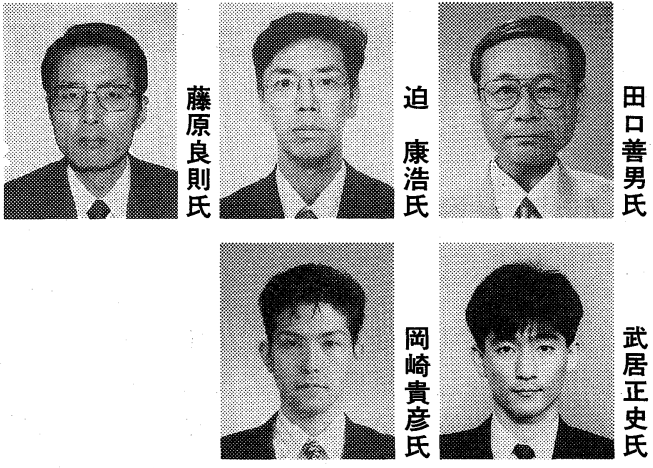

当社では, ポリウレタン構成分子の化学構造（一次 構造）に依存する分子設計から無数の分子が寄り集ま って作る空間構造（高次構造）を変化させて，クリー ニング性と耐久性の向上を四る技術（特開平 5 150697，278045)や，感光体との摩擦係数を制御して, 感光体の傷防止と駆動トルクの低減を図ったり(PAT 出願中), 長鎖活性水素化合物の分子量·分子量分布の 最適化で粘弾性挙動を制御して，より広範井の環境条 件でも正常に機能するブレードの開発を行い（特公平 7 - 113807, 他出願中), 更に, 成形加工時間を大幅に 短縮し，生産性を向上した速硬化ポリウレタンの技術 も実用化しております(特開平 $4-226308$, 他出願中).

これらにより，これまでにない高性能なクリーニン グブレードの開発に成功し，ユーザーの好評を得，当 分野において広くご使用いただいております。

\section{4.おわりに}

$\mathrm{OA}$ 機器用のゴム部品は, 他の産業用部品に比較し, ワンオーダー寸法精度が厳しくかつ微細な異物や気泡 の混入等による欠陥でも即画像に影響が出ることや, 摩擦係数や電気抵抗の制御においても, 環境温湿度や トナー，紙粉等の影響について充分配慮した設計が必 要です.

更に，接触する相手の部材に対しての污染性も重要 なポイントであり，配合材料のブルーム・ブリードか ら，使用する離型剤の選択まで細心の注意が払われて います。

当社は,これらクリーニングブレードの開発におい て得られた技術を活かし，周辺の高機能ゴム部品の開 発に注力して参ります。

今後，情報の大量・高速通信の拡大とともに，電子 写真プロセスは多くの課題を持ちながらますます発展 し，ゴム部品にも多様な機能が要求されてくるものと 予測され，これらに対応できるよう引き続き研究開発 に注力して参りたいと考えております。 